\title{
Why Do Mines Close?
}

\author{
D.C. Laurence School of Mining Engineering, University of New South Wales, Australia
}

\section{SUMMARY}

This paper summarises the early results of a significant and on-going research project investigating the causes and impacts of mine closures over the past 25 years. The closure of the 800 mines provides a wealth of data, obtained from company and government records, interviews with key personnel and other sources. The data includes all Australian States and Territories and all commodities, including metalliferous, coal and industrial minerals. The majority of mine closures were in Western Australia (60\%) followed by New South Wales (20\%) and Queensland (10\%). The most commonly closed mine was a gold mine followed by coal, nickel, base metals and minerals sands operations. Twenty five percent of the mines closed due to resource exhaustion or depletion; $24 \%$ due to high costs, price drops, or declining grades; $8 \%$ due to open pit resource depletion (but with underground reserves remaining) or underground reserves depleted (but plans to open cut remainder) and $7 \%$ due to receivership or voluntary administration. Other significant causes included closure of a downstream industry or loss of markets; adverse geological/geotechnical factors; flooding/inrush; government/political decisions; safety/health or environmental issues or other reasons. The environmental, social and economic impacts of these closures are also significant and include acid mine drainage and impact on mine employees. The outcomes of the research will equip operators and regulators to better manage future mine closures.

\section{$1 \quad$ INTRODUCTION}

In a perfect world, mines would only close when their mineral resources are exhausted. In coal mines for example, the coal seam between the sandstone, shale or conglomerate sedimentary layers would have been completely extracted. Similarly, in hard rock mines, the valuable metals would be completely recovered. However, in the real world, mines extract reserves, not resources, and the grade and tonnage of reserves vary from day to day depending on the commodity price, coal quality or ore grade, further exploration results, as well as geotechnical and other factors.

Occasionally, mines are in the fortunate position of extracting all the original reserves and often exceed these reserves due to favourable commodity prices or exploration successes. Examples include gold mines where a single processing plant has had an extended life by treating ore not just from the original planned open pit, but from a later underground mine or adjacent "satellite" pits.

From a sustainability perspective, these planned mine closures are the easiest to manage. In these cases, time is available for planning, rehabilitation monitoring and trials. Sufficient revenue should have been generated to sustain the expenses associated with mine closure. Mine rehabilitation should have been systematically planned and implemented and the outcomes achieved or progressed satisfactorily. There should have been ample opportunity to overcome any major environmental management issue that may create problems after closure.

In addition, the various stakeholders will be conditioned to the planned closure date. Employees for example can plan to find alternative employment either with the company or elsewhere. The community in which the mine operates and the various layers of government that regulate the mine have the opportunity to work with the management to ensure there will be sustainable benefits from mining activities.

However, due to the variability in commodity price and a host of other factors, mines often close before the planned end of mine life. This situation can create significant problems over the whole range of sustainability issues for the mining company, the community and the government regulator.

This paper presents initial results of a significant research project aiming to investigate why mines close and what are the impacts of those closures. In doing so, it will provide the basis for ongoing development of a predictive model to enable mine operators and regulators to better manage future mine closures. 


\section{$2 \quad$ MINE CLOSURES $1981-2005$}

Coal mining activities can be traced back to the late 18th Century in Australia and indigenous miners commenced tens of thousands of years prior to that. A decision was made to restrict the time span for this research to the "recent" era of mining in Australia. The "recent" era is considered to begin from the 1980s as this was the time that:

- Technological improvements, particularly in the gold mining industry rapidly developed.

- Commodity prices, especially the gold price, increased, creating a boom in exploration as well as the stock market.

- Environmental legislation was introduced into most jurisdictions.

- Mine rehabilitation and environmental management practices were implemented in most if not all Australian jurisdictions.

- Security deposits or bonds were also introduced or significantly increased.

By restricting the data set accordingly, the assumption is that the mines that closed in the 1980s did so in a similar societal context to that which exists today.

The data for this research was sourced from mining company records, government records, personal interviews and other data. It covers all Australian states and territories and includes all commodities, including metalliferous, coal and industrial minerals. Small scale mines were not included. For the purpose of this research, a "closed" mine, is a mine where production ceased for 6 months or more. It may have been a temporary or permanent closure.

Data collected included date of opening; date of closure; commodity; location; temporary/permanent; planned/premature; planned mine life; actual mine life; resource exhausted?; primary reason for closure; secondary reason; environmental issues; community issues; economic issues; OHS issues; governance issues; bond; estimated rehabilitation costs; original land use and final land use.

The data base is large and consists of over 800 mines and 19,000 data entries. This paper describes initial results of an on-going data collation and interpretation project.

The rate of mine closures over the past 25 years is illustrated in Figure 1. It can be seen that between 1981 and 1988, the rate of closure was relatively constant with a mean of around 4 each year. From 1989 until 1995, they increased to around 10 per year. From then until 2005 the number of closures averaged 25 with peaks of 50 in 1998 and 38 in 2003.

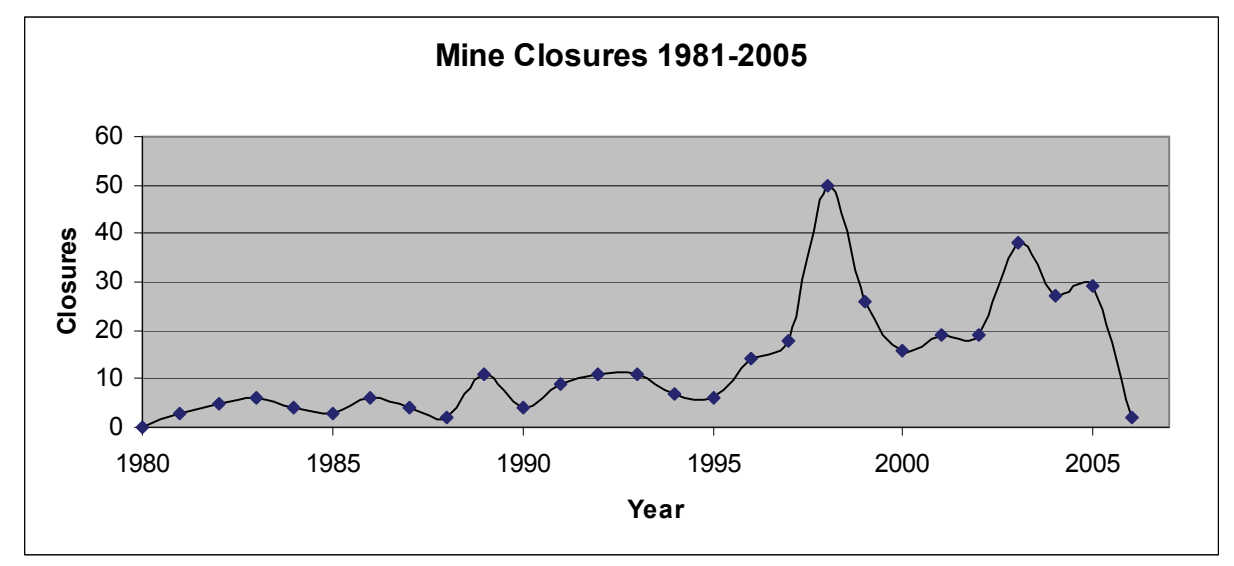

\section{Figure $1 \quad$ Australian mine closures 1981 - 2005}

The early 1980s saw the demise of a number of the copper, uranium, asbestos, base metal and mineral sand mines that flourished in the 1970s (Table 1). For a number of political and other reasons, these commodities would either not be mined again in Australia (asbestos) or, if they were, with severe restrictions (mineral 
sands, uranium). The tin price crash of October 1985 caused the closure of a number of significant and numerous small scale tin mines. Numerous gold mines commenced in the early-mid 1980s spurred on by high gold prices and advances in geology, geophysics, mining and metallurgy. The closures of the 1990s reflect the end of this era, particularly in open cut gold mining. Low gold prices in the late 1990s and early 2000 s contributed to the closure of numerous mines during those years as well. Low nickel prices in the midlate 1990s driven by supply from Russia and other Eastern Bloc countries also contributed to closures of Australian mines.

The flat coal prices of the 1990s also resulted in mines closing, particularly in the Illawarra region of NSW. It can be seen that closures generally reached a peak around 1998, highlighting the impact of flat or declining commodity prices over many years, in all commodities.

In the current (2006) era of historically-high commodity prices, a number of formerly closed mines or marginal prospects are being reactivated. It will be interesting to observe how long these new mines remain open, particularly if prices suddenly drop.

Table 1 Mine closures and the major commodities

\begin{tabular}{|l|l|}
\hline Year & \multicolumn{1}{|c|}{ Major Commodity } \\
\hline 1981 & Copper (1 closure), scheelite (1), uranium (1) \\
\hline 1982 & $\begin{array}{l}\text { Coal (1), gold (1), iron ore (1), tin (1), uranium } \\
(1)\end{array}$ \\
\hline 1983 & $\begin{array}{l}\text { Asbestos (1), coal (1), iron ore (1), min sands (1), } \\
\text { lead \& zinc (1) }\end{array}$ \\
\hline 1984 & Coal (4) \\
\hline 1985 & Coal (1), tin (1) \\
\hline 1986 & Coal (3), tin (1) \\
\hline 1987 & Coal (1), min sands (1) \\
\hline 1988 & Coal (2) \\
\hline 1989 & Iron ore (3) \\
\hline 1990 & Gold (1), nickel (1) \\
\hline 1991 & Gold (5), coal (2) \\
\hline 1992 & Gold (5), iron ore (2) \\
\hline 1993 & Coal (5), gold (4) \\
\hline 1994 & Gold (5) \\
\hline & \\
\hline 192 &
\end{tabular}




\begin{tabular}{|c|c|}
\hline Year & Major Commodity \\
\hline 1995 & Gold (3) \\
\hline 1996 & Gold (6), coal (4), copper (2) \\
\hline 1997 & Gold (10), coal (4) \\
\hline 1998 & $\begin{array}{l}\text { Gold (23), nickel (6), coal (6), zinc \& lead (5), } \\
\text { iron ore (3), min sands ( } 2)\end{array}$ \\
\hline 1999 & Gold (6), coal (5), min sands (5), zinc \& lead (3) \\
\hline 2000 & Gold (6), coal (3), zinc \& lead (3) \\
\hline 2001 & Gold (11), coal (6) \\
\hline 2002 & Coal (6), gold (5), nickel (3) \\
\hline 2003 & $\begin{array}{l}\text { Gold (13), coal (5), zinc \& lead (6), min sands (4), } \\
\text { copper (2), tin (2) }\end{array}$ \\
\hline 2004 & Gold (15), coal (6) \\
\hline 2005 & Gold (15), nickel (3), copper (2) \\
\hline
\end{tabular}

Closures by commodity or mineral are illustrated in Figure 2. Gold is dominant. There are a number of reasons for this of course including:

- Relative abundance of gold deposits in Australia.

- Relative short mine life.

- Widely fluctuating gold price (and exchange rates).

- Technical challenges including ore reserve estimation.

Coal mines also closed in numbers in the period, particularly in the Illawarra and Central Coast areas of NSW and the Collie coal field of WA. 


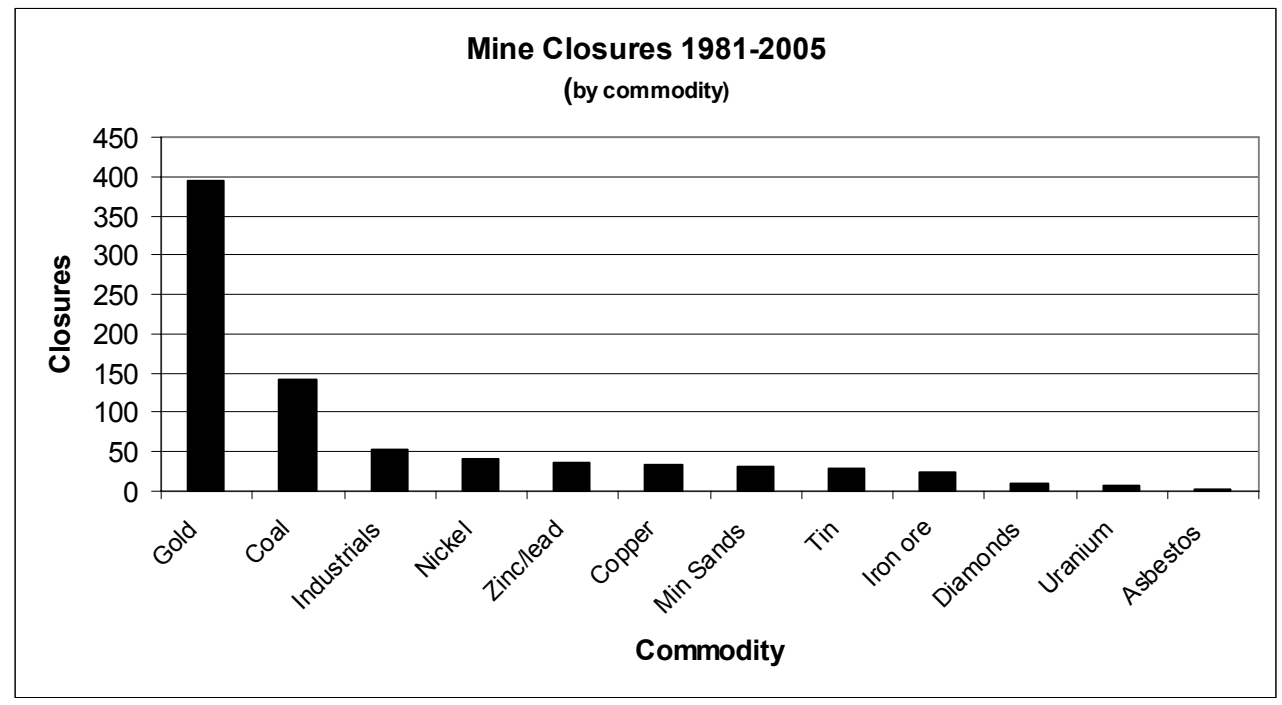

Figure 2 Mine closures 1981-2005 (by commodity)

As would be expected, most of the closures were in Western Australia, followed by NSW and Queensland as illustrated in Figure 3. Few mines currently operate in the Northern Territory, however many have closed (22) in the past 25 years. Similarly the Tasmanian mining industry is operating at a reduced level to that which operated in the recent past.

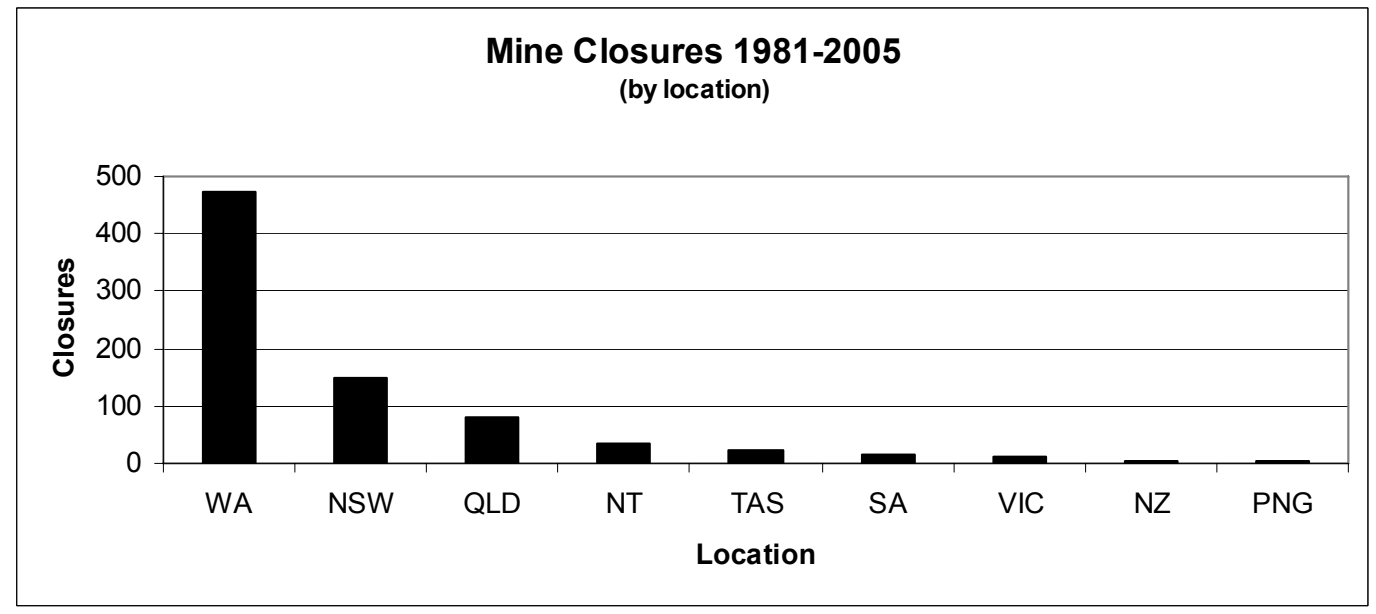

Figure 3 Mine Closures 1981-2005 (by location)

\section{$3 \quad$ WHY DO MINES CLOSE?}

There are a plethora of reasons why mines close prematurely. The research for this project indicates that the majority of mines that have closed in the past 25 years have been unplanned closures due to reasons other than exhaustion or depletion of reserves.

Some of the reasons for unplanned mine closures are:

- Economic, due to either low commodity price or high costs leading at times to company voluntary administration or receivership.

- Geological, due, for example, to an unanticipated decrease in grade or size of the ore body.

- Technical, due to adverse geotechnical conditions or mechanical/equipment failure.

- Regulatory, due to safety or environmental breaches. 
- Policy changes, which occur from time to time, particularly when governments change.

- Social or community pressures, particularly from NGOs.

- Closure of downstream industry or markets.

- Flooding or inrush (Laurence, 2006).

In some countries, unplanned mine closures are often due to political instability including coups and civil wars. The closure of the Bougainville copper mine and the Gold Ridge mine in the Solomon Islands highlight these risks.

\subsection{Closure Due to Resource Depletion}

Figure 4 illustrates the principal factors that led to Australian mine closures in the last 25 years. It can be seen that around 25 per cent of mines closed due to the exhaustion of the economic resource. Underground coal mines, for example in the Illawarra, as well as Tasmanian base metal mines feature in this category. Mineral sand mines on both the East and West Coasts and uranium mines have also closed after the resource is exhausted.

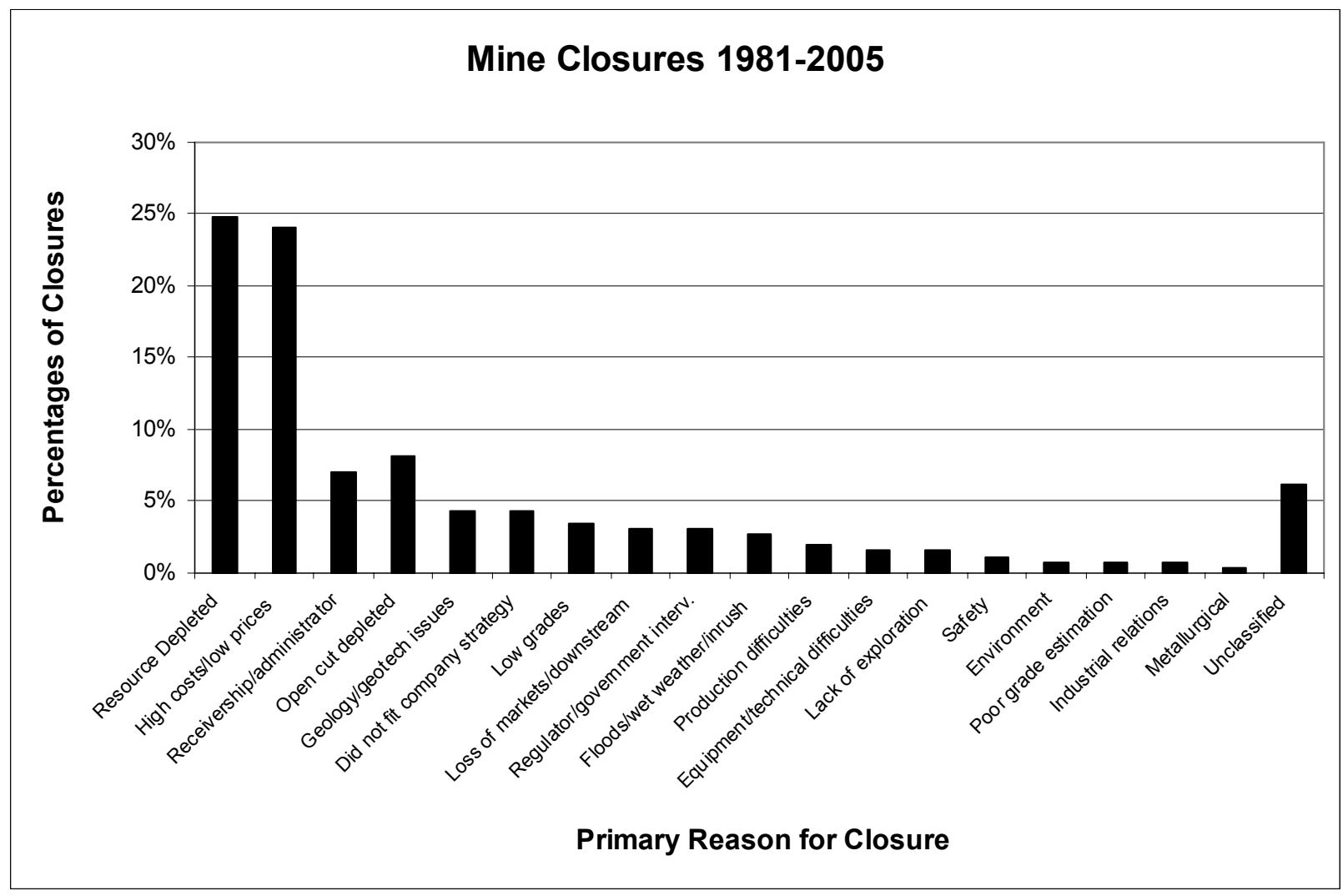

Figure 4 Mine closures 1981-2005 (primary reason for closure)

\subsection{Closure Due to Economic Reasons}

Until around 2005, the mining industry operated in an environment of steadily declining global commodity prices. In the last couple of years, due mainly to unprecedented demand by China and to a lesser extent, India, most commodity prices have strengthened. Coal, iron ore, base metals, nickel, gold and other commodity prices are at historic highs. This has implications of course for mine closure, with a number of closed mines being reactivated. Examples include the formerly "mothballed" Lennard Shelf zinc operations, revived by TechCominco, and Aztec's Koolan Island iron ore project. 
One of the best-known examples of "mass" mine closures occurred in October 1985, when the price of tin dropped dramatically after the collapse of the International Tin Agreement at the London Metal Exchange. After the price dropped more than $50 \%$, from US\$5.40/pound to $\$ 2.50$, numerous mines could no longer remain in operation.

The old saying that "gold mines never die, they just rest for a while" reflects the history of gold mines in the past 20 years, as much as it did since the 1880s in Australia. The reasons are due to price (and exchange rate) variability, new geological approaches and improvements in exploration, mining and metallurgical technology. Many of the gold mines listed in the database are on "care and maintenance", reflecting the owner's reluctance to shut them permanently. Many closed in the past 25 years due to higher costs, a low gold price, or low grades.

\subsection{Closure Due to Cessation of Open Pit or Underground Workings}

Many mines, particularly gold, closed in the recent past due to exhaustion of the open pittable reserve. The resource often continued at depth and in a number of cases, the mines were reopened as underground mines, with a portal and decline driven from a lower bench of the open pit. In other instances, the closure was due to the exhaustion of the oxide ore while the viability of mining the transitional and primary (sulphide) ore was assessed. Alternatively, examples exist where the accessible underground reserves are depleted but there are open pittable reserves available. Examples can be found in both hard rock (e.g. McArthur River) and coal.

\subsection{Closure Due to Receivership or Administration}

There have been a number of notable examples of mines closing when a receiver or an administrator is appointed. In these cases, it is often not possible to dispose of the mine's assets as a "going concern" resulting in a sale of the tenements and an auction of equipment and machinery. Examples include base metal mines CSA, Woodlawn, Selwyn and the recent Gympie gold mine closure. The Mount Todd mine (renamed Yimuyn Manjerr) was reopened in 1999 but closed again in 2000 resulting in an auction of the mine site's assets. The Oakdale coal mine in NSW was placed in voluntary receivership with adverse outcomes for the industry and the community. The action resulted in a 24 hour national coal strike, estimated to have cost Australia \$1 million per hour and generated extreme anti-mining publicity in the media. The construction and commissioning phase of a mine's life can be a high risk process and two mines have closed in recent years as a result of escalating costs during this critical period.

\subsection{Closure Due to Loss of Markets or Downstream Processing}

Almost 3 per cent of mines shut down due to the loss of their market or the closure of downstream industries. They mainly included coal mines affected by closures of power stations (e.g. Swanbank, Huntley and Swamp Creek).

\subsection{Closure Due to Geological or Geotechnical reasons}

Mining takes place in a non-homogeneous rock mass, which varies from site to site (Laurence 2006). Imperfections in the rock in the form of joints, cleavages, cleats, and other planar weaknesses, combined with faults, shear zones and hydrological issues, can lead to failure of the rock mass. Falls in underground workings have caused the premature closure of many mines, including the Tom's Gully Mine in the Northern Territory, where the decline intersected a fault and the development failed to overcome the resultant poor ground conditions. The most spectacular closure in Australia in recent years due to geotechnical reasons was the 1998 hanging wall or stope failure at the Browns Creek Mine in central NSW, and the subsequent inrush of water and subsequent filling of the mine. Other examples include an underground base metal mine in NSW which has closed twice in the last 10 years for extended periods due to major falls of ground. Similarly, the Cumnock coal mine in the Hunter Valley of NSW closed in 2003 due to "adverse geological conditions". 
Pit slope failures in open pit mines can cause permanent mine closures and most recently caused the deaths of eight workers at the massive Grasberg open cut mine in Indonesia, operated by PT Freeport. The mine closed temporarily after this incident.

High stresses, seismic events, falls of ground, stope failures have contributed also to the sterilisation of large amounts of ore in numerous mines in WA and elsewhere, leading to the early closure of these mines.

\subsection{Closure Due to Grade Estimation Problems}

Ore reserves are estimates based on the best available data provided by geological, geophysical, geochemical, and drilling techniques, and by other relevant means. An over-estimation of the grade and tonnage of a deposit is a common reason for a mine to close prematurely. The feasibility study of the Mount Todd Mine in the Northern Territory predicted head grades at over one gram per tonne but recoveries averaged a little over 0.8 grams for the life of the mine. The mine closed after one year, although the expected mine life was more than nine years.

\subsection{Closure Due to Flooding}

Flooding was the primary cause of a number of mine closures in recent years. They include both underground and open pit mines in WA and elsewhere and included the Bannockburn and the Emu mine in the Eastern Goldfields with the resultant loss of 6 lives. Inrush also caused the deaths of four coal miners and the closure of the Gretley Coal Mine in NSW in 1996. The social and community fallout after Gretley has been considerable, including the prosecutions of the company and individual managers. In an unusual case, the Wingecarribee Peat mine in NSW closed after a flood relocated the peat resource.

\subsection{Closure Due to Major Safety or Health Issues}

Examples of sudden mine closures after a major safety issue, usually involving fatalities, include Gretley (subsequently re-opened with a new name) and the Renison tin mine in Tasmania. The Northparkes Mine temporarily closed in 1999 following an incident resulting in the deaths of four personnel. The intense media interest following the seismic event at the Beaconsfield gold mine in April 2006 brought the issue into the public arena. This mine remains closed 2 months after the event while various official enquiries take place.

\subsection{Closure Due to Metallurgical Problems}

The recent closures of the Bulong and Cawse nickel laterite mines demonstrate the importance of ensuring the metallurgical test work on the ore is adequate. Mount Todd also had metallurgical difficulties with the hardness of the ore and its mineralogy, both contributing to higher costs and premature closure. The Beenup mineral sand operation closed due to the inability to handle the high sulphur clays encapsulating the heavy mineral.

\subsection{Closure Due to Equipment or Mechanical failure}

Mine closures due to equipment failure have been a part of mining history. One of the more spectacular equipment failures to result in the premature closure of the mine in recent times was the Grey River dredge on New Zealand's South Island. The dredge was of an inappropriate design for the alluvial ore reserve. Similarly, the Beenup mineral sand project encountered ironstone bars during the dredging operation, apparently not been identified during exploration. This led to significantly increased operating costs and resulted, along with other unresolved operating issues, in the premature closure of the operation.

\subsection{Closure Due to Regulatory Pressure}

Government inspectors have the statutory power to close mines due to environmental or safety breaches. The most frequent examples are due to safety issues as indicated above. Closures due to environmental issues are actually rare in Australia. A recent exception is the closure of the Ranger uranium mine due to elevated levels of contaminants that was accidentally distributed through the drinking water system. Longer closures are associated with international incidents including the cyanide spill at the Baia Mare mine in Romania and the tailings leak at the Mt Kasi Mine in Fiji. 


\subsection{Closure Due to Government Policy}

Apart from operations at North Stradbroke Island, mineral sand mining on the coasts of New South Wales and Queensland has ended. This once flourishing industry no longer has access to the significant, high grade resources which remain, mostly in National Parks. The operations of Dillingham were prematurely closed by the Federal Government in 1976 at Fraser Island in Queensland after the Fraser Island Environmental Inquiry found that mining constituted a significant threat to the island's environment. Other premature closures in more recent years due to government decision-making included Bridge Hill Ridge, Jerusalem Creek and Saltwater. The re-opening of the Woodsreef asbestos mine in northern NSW was abandoned due to the controversy surrounding the mining of asbestos.

\subsection{Closure Due to Community or Landowner Opposition}

The Timbarra gold mine in NSW closed in 2001 due in part to the continued opposition to its operation by an alliance of opposition groups. High costs, low grades sent to the mill and persistent wet conditions during its construction and early operations also contributed to its premature closure. The Jabiluka Uranium Mine operated as a development operation only (i.e. no uranium production) in the face of highly organised opposition from environmental and community groups for almost two years before operations halted. The owner, ERA Limited, has indicated it will not recommence mining at Jabiluka until the traditional owners are supportive of mining.

\subsection{Closure Due to Mine Design or Planning Decisions}

In some cases, the mining method chosen has contributed to the premature closure of the mine. Caving methods in underground metalliferous mining are cost-effective but are relatively inflexible. If the orebody is not conducive to caving, large areas can be sterilised and the mine prematurely closed. Examples include the Great Victoria mine in WA. The Northparkes block cave mine temporarily closed in 1999 after an airblast caused the deaths of four persons. Occasionally a mine will not sustain a large scale stoping method and mine planning engineers have to change to narrow vein methods for the mine to continue operating. This in turn will lead to higher costs and contribute to premature closure.

\subsection{Closure Due to Other Reasons}

Occasionally mines close before their reserves are exhausted due to reasons other than those indicated above. For example, the coal mining operations at Catherine Hill Bay in NSW closed after the company was sold to a buyer who wanted to develop the area for its prime real estate appeal. An industrial dispute closed the Gordonstone coal mine for over 18 months. Environmental issues including impact on the aquifer forced the Tomago mineral sands mine to close. Finally, closures for short or long periods often occur when companies sell the mines to others or there is a merger or takeover. For example, the Windimurra Vanadium mine closed recently in WA when the new owner decided it was unviable.

\section{$4 \quad$ IMPACTS OF CLOSURE}

Although successful mine closures have occurred in the past 25 years, it seems the majority of premature closures have produced unsatisfactory outcomes.

The primary environmental impacts among the 800 mines being analysed in the current research project are illustrated in Figure 5. The most significant is Acid Mine Drainage (AMD). Although AMD is commonly associated with gold mines, base metal and coal mine closures can also be affected. One of the major problems with AMD is that there is no guarantee, as demonstrated by a number of mines in northern Australia, that state-of-the-art techniques will solve the AMD issue on a particular mine site, a number of years later. Other major environmental issues include disposal of tailings, open pit voids, waste dumps and water quality generally. 


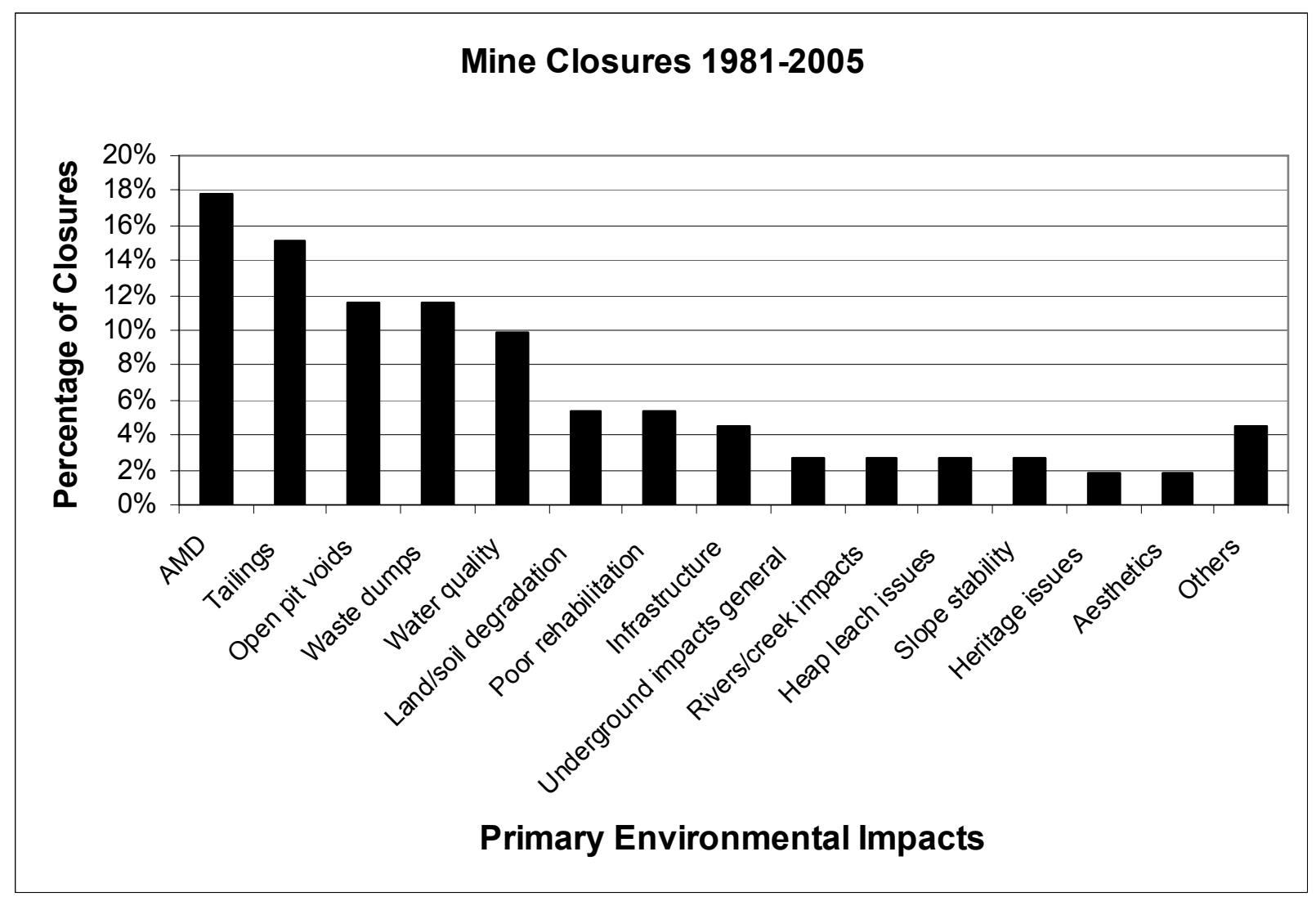

\section{Figure $5 \quad$ Mine closures 1981-2005 (primary environmental impacts)}

The most common socio-economic issue was the impact that closure can have on employees at the mine site, Figure 6. These issues have been highlighted in a number of high profile cases including the Oakdale, Woodlawn, Hillgrove and CSA closures in NSW in the past decade. The impact of Tasmanian mine closures in the 1980s on employees was also severe (Neil et al., 1992). A number of case studies exist of companies doing an excellent job in planning to reduce the impact on employees (e.g. see Laurence, 2002).

Two other significant socio-economic impacts include the impact on employees of other businesses and the impact on the local and regional economies. Mine closures can directly lead to the death of towns, particular in a single mine or single commodity town such as those on the west coast of Tasmania (Neil et al., 1992). The sterilization of vast amounts of ore or coal by premature closure is prevalent and has longer term impacts on society. Innovative efforts to joint venture with indigenous Australians have also been derailed by premature mine closures (e.g. the 1995 Mirrkworlk Joint Venture at the Mt Todd gold mine). 


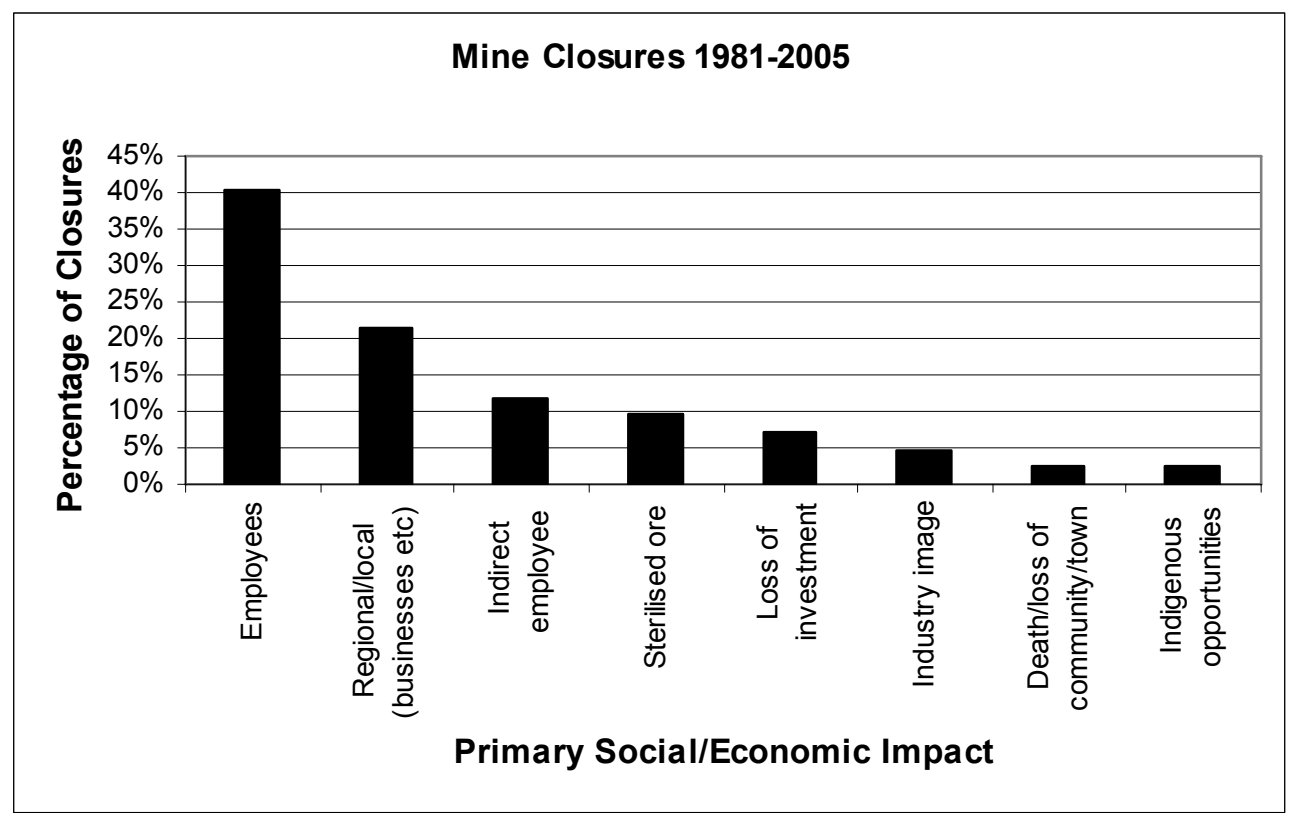

\section{Figure $6 \quad$ Mine closures 1981-2005 - primary social/economic impact}

If mine closures are not properly planned then OHS issues can also arise as illustrated in Figure 7. The most common issue identified in the research to date includes the presence of vertical openings including shafts, trenches or collapsed stopes. Open pit voids have an OHS component as well as the obvious environmental impact. Subsidence is a major issue with longwall coal mines and increasingly becoming an issue with hard rock underground caving systems in Australia.

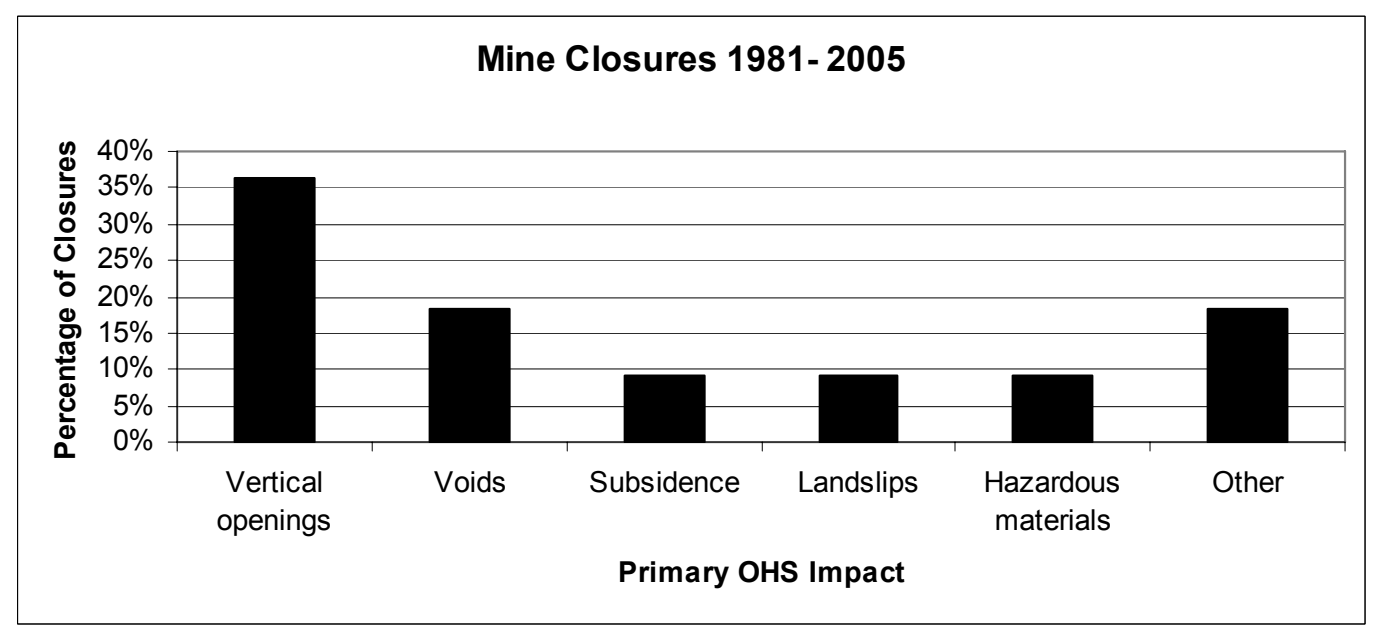

Figure 7 Mine closures 1981-2005 - primary OHS impact

\section{OTHER ISSUES}

Other data currently being collected includes the estimated cost of rehabilitation compared with the amount of government-imposed security deposits or bonds. The average bond over the past 25 years was approximately $\$ 1.75$ million. The estimated cost of rehabilitation was much higher at $\$ 10.8$ million. Due to difficulty in obtaining this data from both regulators and companies, these estimates represent a sample of mines only. However, it does clearly represent the discrepancy between the two sums. 


\section{MODELLING MINE CLOSURE}

Interpretation of the data will assist in the development of predictive modelling to enable both mine operators and regulators to better understand the often complex outcomes of a closed mine. It has been shown (e.g. Laurence 2001, 2006) that the factors influencing mine closure can be modelled. Models such as this can be a valuable tool for decision-makers to assess the major closure risks at individual mine sites in a structured, systematic manner both qualitatively and quantitatively. This, in turn, facilitates comparisons between the closure issues at a single site as well as between different mines.

\section{CONCLUSION}

A preliminary analysis of over 800 mines that closed in Australia in the last 25 years clearly demonstrates that most mines do not close when the economic resource is extracted in a planned and systematic approach. Most close for other reasons including low commodity prices, high costs, lower than expected grades, loss of markets, metallurgical problems, geological or geotechnical problems, catastrophic incidents and/or a myriad of other reasons. The challenge for mine management and regulators therefore is to ensure that they are aware of these various closure risks and to plan accordingly so that mine closure does not result in adverse safety, environmental, community and economic outcomes. The data collected in this research project will facilitate the continued development of a predictive model to assist operators and regulators in this planning goal.

\section{ACKNOWLEDGEMENTS}

The author gratefully acknowledges the valuable assistance of personnel who kindly provided much of the data for this research. In particular personnel from the WA Department of Industry and Resources, the WA Department of Consumer Protection and Environment, the NSW DPI (Mineral Resources), the NT Department of Primary Industry, Fisheries \& Mines, the Tasmanian Department of Infrastructure, Energy and Resources, the Queensland Department of Natural Resources and Mines and the Queensland Environmental Protection Agency.

\section{REFERENCES}

Laurence, D.C. (2001) Classification of Risk Factors Associated with Mine Closure, Mineral Resources Engineering, Vol.10, No. 3, pp. 315-331.

Laurence, D.C. (2002) Optimising Mine Closure Outcomes for the Community - Lessons Learnt Minerals and Energy, Raw Materials Group, Vol. 17 No.1, pp. 27-34.

Laurence, D.C. (2006) Optimisation of the Mine Closure Process, Journal of Cleaner Production, Volume 14, Issues 34, pp. 285-298 Elsevier Science Ltd.

Neil, C., Tykkylainen M. and Bradbury, J. (eds) (1992) Coping with Closure: An International Comparison of Mine Town Experiences, Routledge, London, ISBN 0415066514. 